\title{
Synchronous Radiation Exposure and X-Ray Room Access Control: A Proposed Novel Approach to Radiation Protection of Staff, Patients and the Public in Diagnostic Radiography
}

\section{Ohagwu $^{1 *}$, PC Ifionu ${ }^{1}$ and SU Ufoaroh ${ }^{2}$}

${ }^{1}$ Department of Radiography and Radiological Sciences, Nnamdi Azikiwe University Nnewi Campus, Nigeria

${ }^{2}$ Department of Electronic and Computer Engineering, Nnamdi Azikiwe University, Nigeria

Submission: February 10, 2017; Published: May 04, 2017

*Corresponding author: Christopher Chukwuemeka Ohagwu, Department of Radiography and Radiological Sciences, Faculty of Health Sciences and Technology, Nnamdi Azikiwe University Nnewi Campus, P. M. B. 5001 Nnewi, Anambra State, Nigeria, Tel: +2347061195362;

Email: cc.ohagwu@unizik.edu.ng

\section{Abstract}

This aim of this article is to propose an automatic door locking system for the $\mathrm{x}$-ray room entrance door which is designed to enhance the radiation protection of staff, patients, and the public. The automatic door locking system is designed to restrict unauthorized individuals from gaining access to the x-ray room during $\mathrm{x}$-ray exposure. The automatic door locking system for the $\mathrm{x}$-ray room entrance, which is synchronized with the x-ray exposure mechanism, was conceived. The system was then designed and built with the aid of circuit diagrams. The performance testing and evaluations carried out before and after coupling of the components of the system showed the system could be adopted in the design, manufacture and installation of future x-ray equipment in diagnostic and therapy rooms.

Keywords: Automatic door locking system; Radiation protection; X-ray room access control

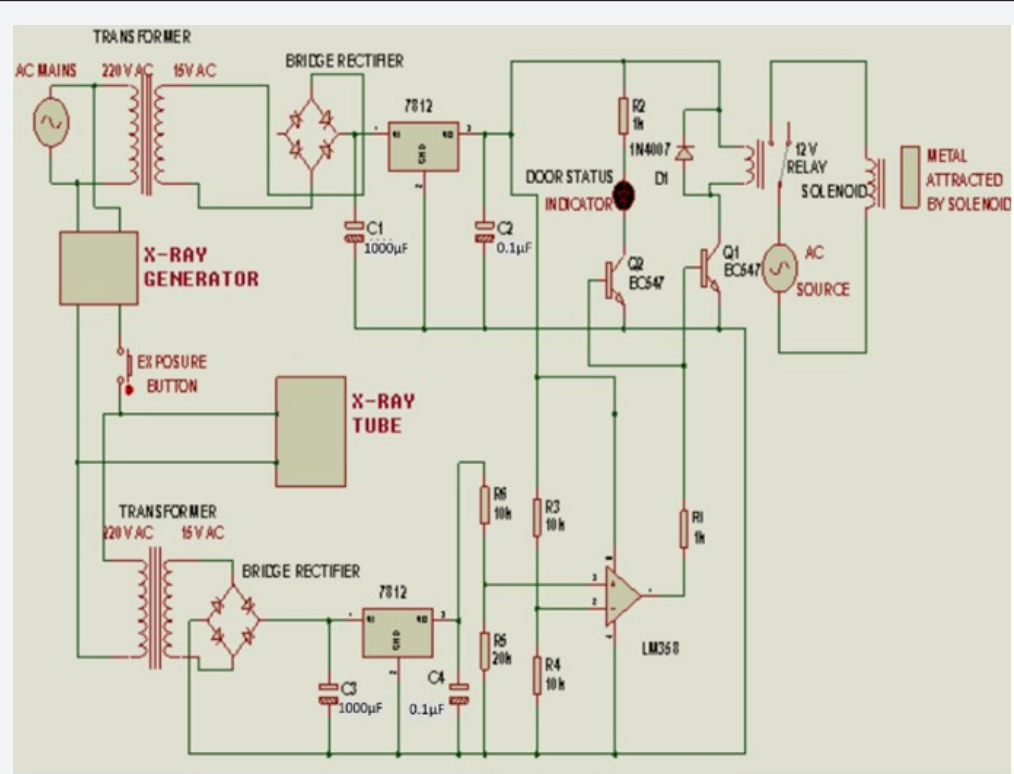

Figure 1: The complete circuit diagram of the system. 


\section{Current Trends in Clinical \& Medical Imaging}

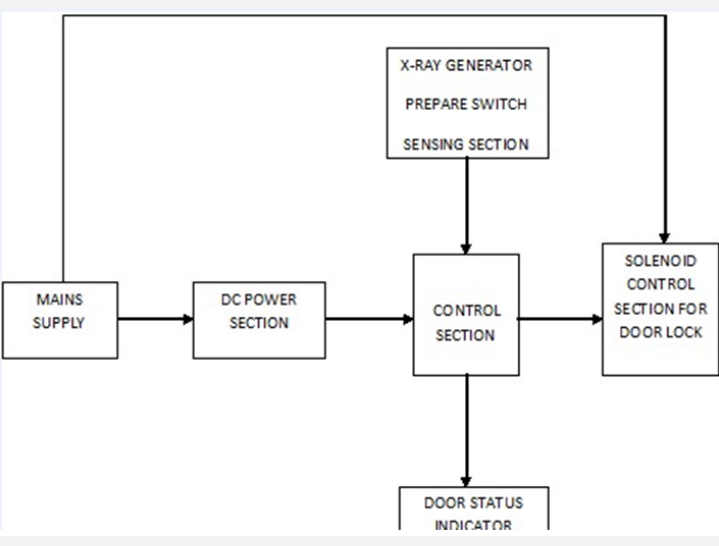

Figure 2: A block diagram the automatic door locking system.

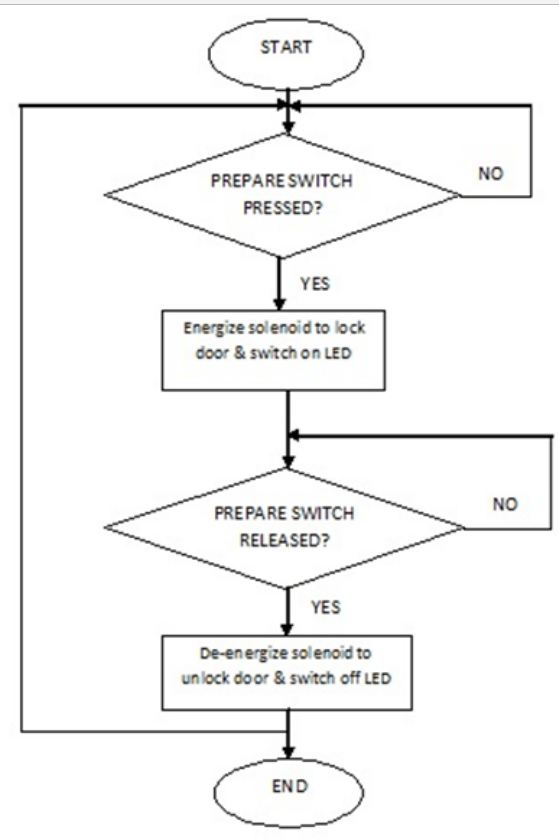

Figure 3: Operational flow cahrt of the automatic door locking system.

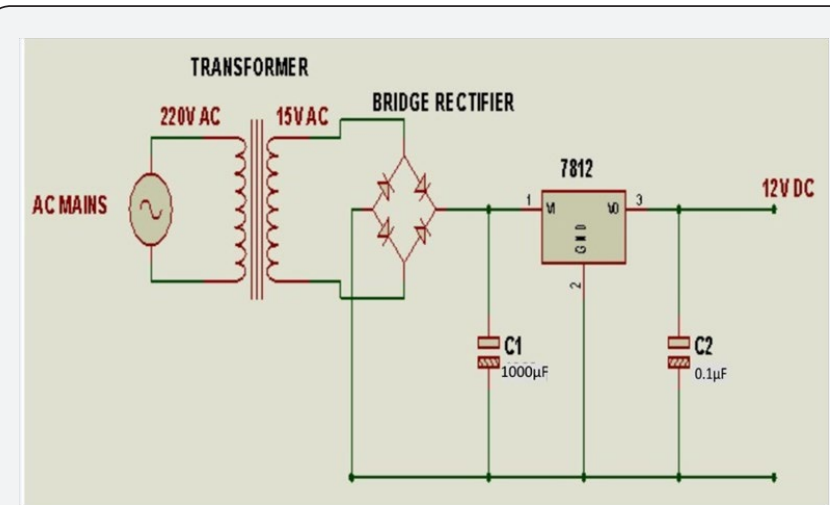

Figure 4: The pover input section of the automatic door locking system.

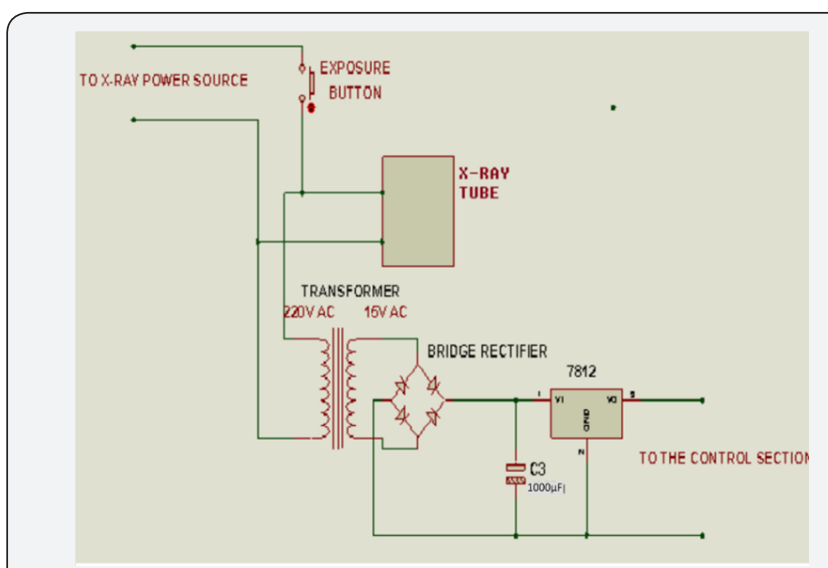

Figure 5: The sensing circuitry for the automatic locking system.

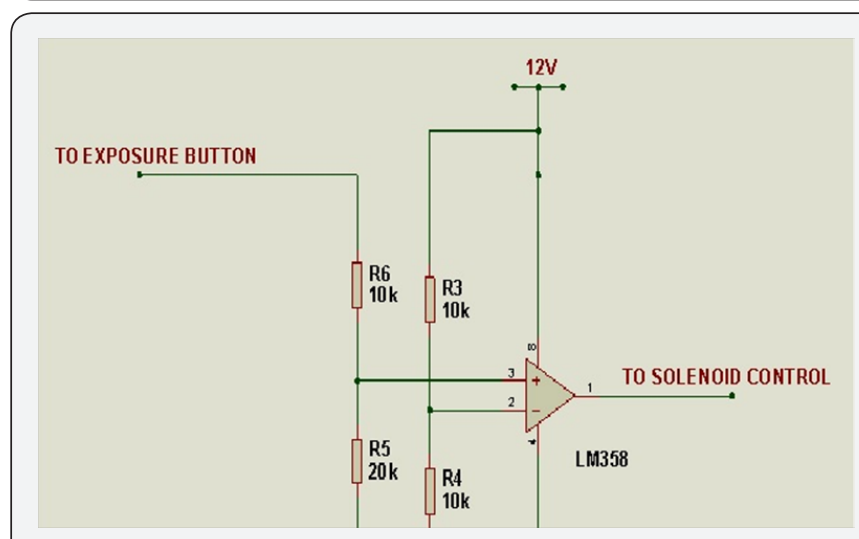

Figure 6:The control circuitry for the automatic locking system

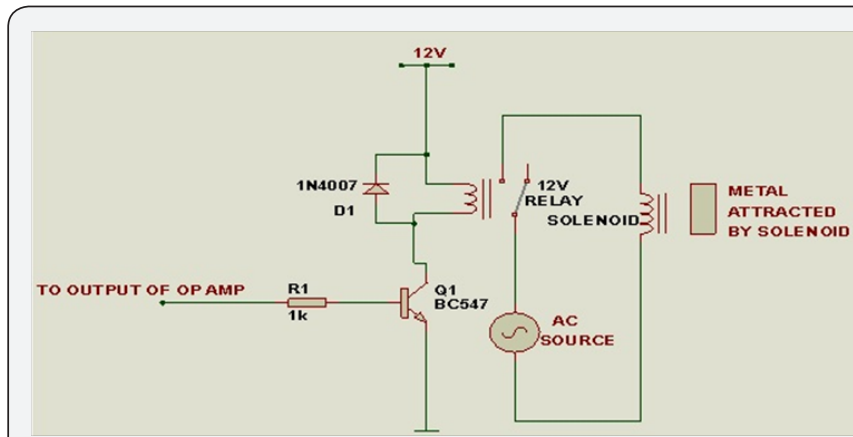

Figure 7:The magnetic control circuitry for the automatic locking system.

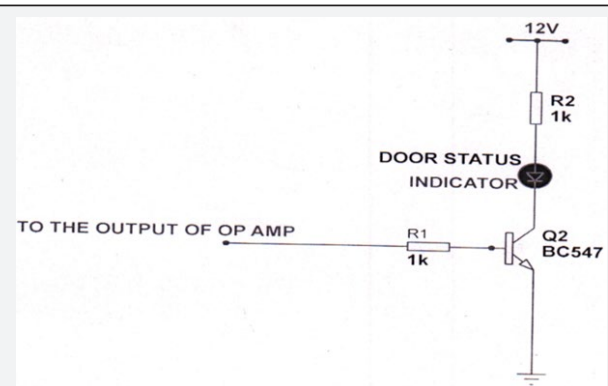

Figure 8: Circuit diagram of the door status indicator. 


\section{Current Trends in Clinical \& Medical Imaging}

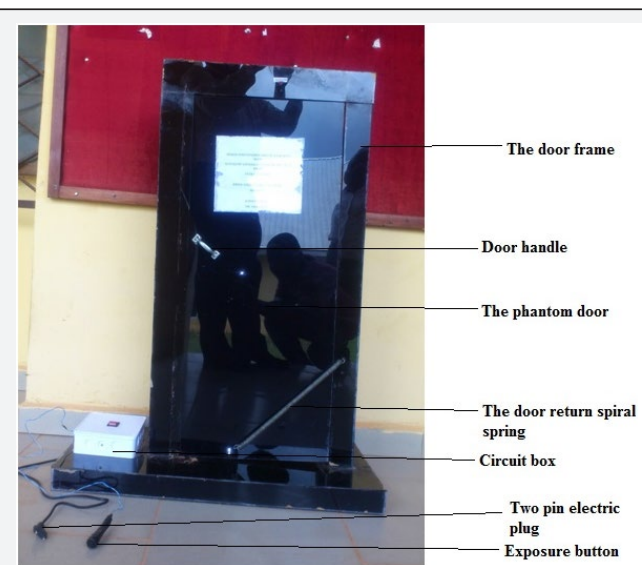

Figure 9: An automatic locking system built in to Perspex phantom door.
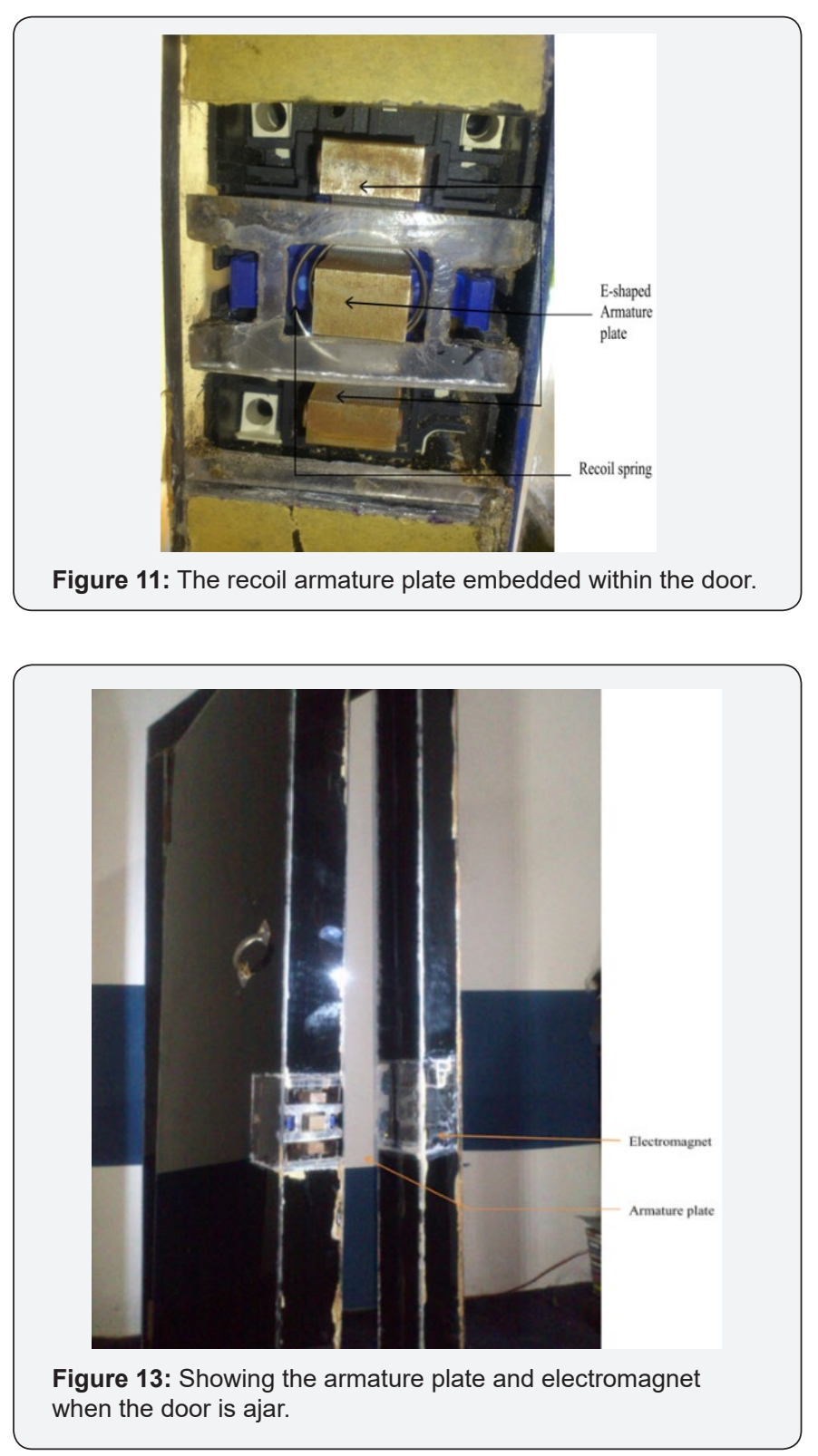
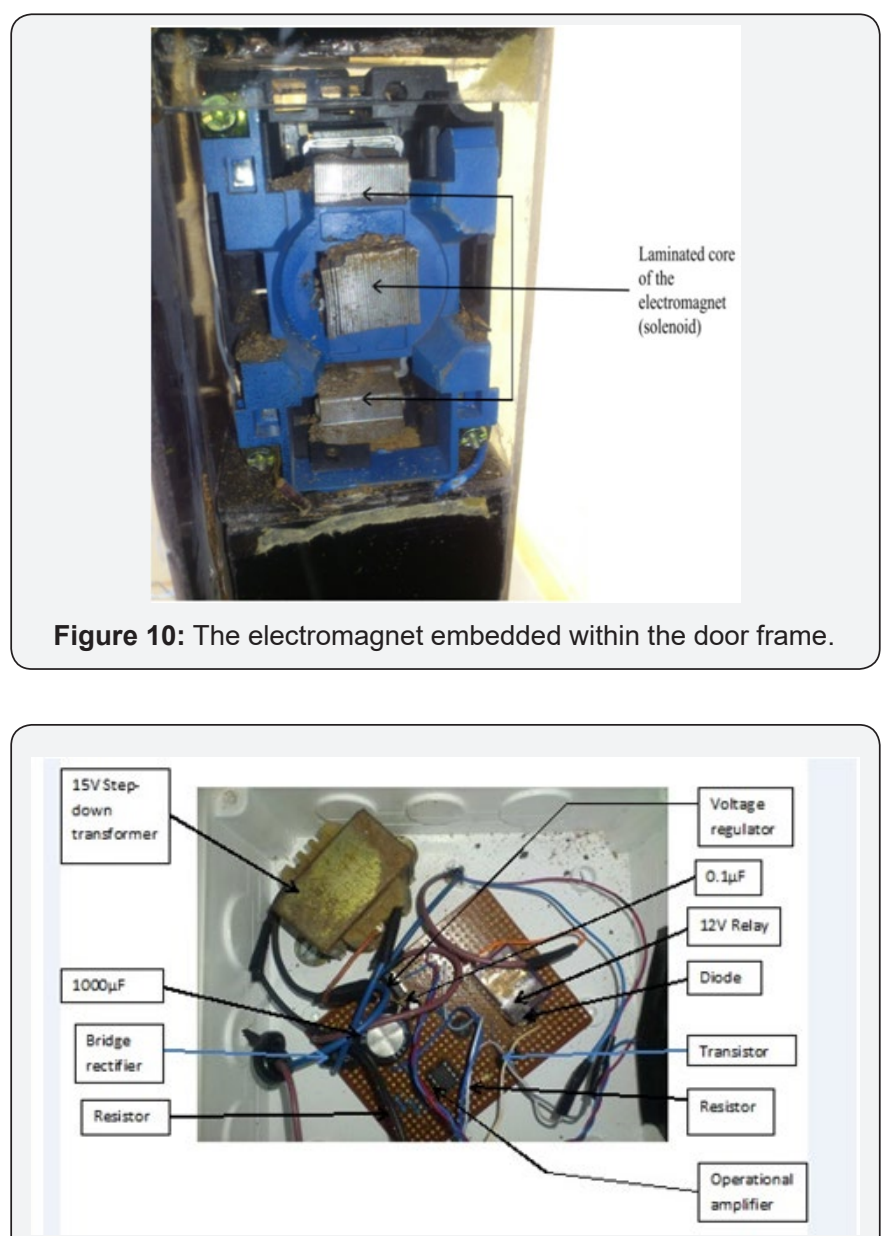

Figure 12: The recoil armature plate embedded within the door.

Table 1: The results of magnetic strength test at 220V.

\begin{tabular}{|c|c|c|c|}
\hline \multicolumn{2}{|c|}{$\begin{array}{c}\text { Without the Return } \\
\text { Spring }\end{array}$} & \multicolumn{2}{c|}{ With the Return Spring } \\
\hline $\begin{array}{c}\text { Distance } \\
(\mathrm{cm})\end{array}$ & Contact & $\begin{array}{c}\text { Distance } \\
(\mathrm{cm})\end{array}$ & Contact \\
\hline 5.0 & $\begin{array}{c}\text { No contact } \\
\text { established }\end{array}$ & 5.0 & No contact established \\
\hline 4.5 & $\begin{array}{c}\text { No contact } \\
\text { established }\end{array}$ & 4.5 & No contact established \\
\hline 3.5 & $\begin{array}{c}\text { Magnetic field } \\
\text { felt }\end{array}$ & 3.5 & \begin{tabular}{c} 
Slight magnetic field felt \\
\hline 3.0
\end{tabular} \\
\hline & $\begin{array}{c}\text { Contact firmly } \\
\text { established }\end{array}$ & 3.0 & $\begin{array}{c}\text { Not enough magnetic } \\
\text { field to establish a } \\
\text { contact }\end{array}$ \\
\hline & & 2.5 & $\begin{array}{c}\text { Contact firmly } \\
\text { established }\end{array}$ \\
\hline
\end{tabular}




\section{Current Trends in Clinical \& Medical Imaging}

Table 2: Variation of magnet's ability to make contact with the armature plate with the applied voltage.

\begin{tabular}{|c|c|}
\hline Voltage (V) & $\begin{array}{c}\text { Maximum Distance at which Contact was Established } \\
\text { (cm) }\end{array}$ \\
\hline 150 & No contact \\
\hline 160 & 0.00 \\
\hline 170 & 0.3 \\
\hline 180 & 0.5 \\
\hline 190 & 1.0 \\
\hline 200 & 1.0 \\
\hline 210 & 1.5 \\
\hline 220 & 2.0 \\
\hline
\end{tabular}

Table 3: Result of the test of the ability of the door spring to close the door.
\begin{tabular}{|c|c|}
\hline Distance (cm) & Closure \\
\hline 22 & Closed but not tight \\
\hline 25 & Fairly tight \\
\hline 28.5 & Firmly tight \\
\hline
\end{tabular}

Table 3: Result of the test of the ability of the door spring to close the door.

\section{Your next submission with Juniper Publishers will reach you the below assets}

- Quality Editorial service

- Swift Peer Review

- Reprints availability

- E-prints Service

- Manuscript Podcast for convenient understanding

- Global attainment for your research

- Manuscript accessibility in different formats

( Pdf, E-pub, Full Text, Audio)

- Unceasing customer service

Track the below URL for one-step submission https://juniperpublishers.com/online-submission.php 